\title{
LIQUIDUS SURFACE AND SPINODAL OF Fe-B-C ALLOYS
}

\author{
(D) Natalia Yu. Filonenko ${ }^{a, b *}$, (i) Alexandra N. Galdina ${ }^{c}$ \\ aState Institution "Dnipropetrovsk Medical Academy of the Ministry of Health of Ukraine" \\ 9, Vernadsky Str., Dnipro,49044, Ukraine \\ ${ }^{b}$ Z.I. Nekrasov Iron and Steel Institute of National Academy of Sciences of Ukraine \\ 1, Akademika Starodubova Square, Dnipro, 49107, Ukraine \\ 'Oles Honchar Dnipro National University \\ 72, Haharina Ave., Dnipro, 49010, Ukraine \\ *Corresponding Author: natph2016@gmail.com
}

Received 24 November 2019; revised December 4, 2019; accepted December 23, 2019

In this work the study is performed for the specimens of Fe-B-C alloys with boron content of $0.005-7.0$ wt. \% and carbon content of 0.4-6.67 wt. \%, the rest is iron. According to the findings of microstructure analysis, XRD and differential thermal analyses, the primary phases and the temperatures of their formation are determined. Depending on boron content (in the range of $1.5-8.80 \mathrm{wt}$. \%) and carbon content $(0.5-6.67 \mathrm{wt}$. \%) in the Fe-B-C alloys, the primary phases in the process of crystallization are $\gamma$-Fe, boron cementite $\mathrm{Fe}_{3}(\mathrm{CB})$ and boride $\mathrm{Fe}_{2} \mathrm{~B}$. The outcomes of the experiment carried out in this work determine the phase composition and phase transformations occurring in the alloys and the liquidus surface is constructed. The findings show that the liquidus temperature for Fe-B-C system alloys is low compared to binary Fe-B and Fe-C alloys. At the liquidus surface of the Fe-B-C alloys, there is a point at boron content of $2.9 \mathrm{wt} \%$ and carbon content of $1.3 \mathrm{wt}$ \% with the lowest temperature of $1375 \mathrm{~K}$ and it is the point of intersection of monovariant eutectics. This fact is in a good agreement with the results of other authors. The microstructure of alloys located at the curves of monovariant eutectics is represented by the $\gamma-\mathrm{Fe}+\mathrm{Fe}_{2} \mathrm{~B}$ and $\gamma-\mathrm{Fe}+\mathrm{Fe}_{3}(\mathrm{CB})$ eutectics and the primary crystals of $\mathrm{Fe}_{2} \mathrm{~B}$ iron boride in the shell of $\mathrm{Fe}_{3}(\mathrm{BC})$ boron cementite. In this paper it is shown experimentally the existence of a quasi-binary section and the coordinates of the peritectic point are fixed: the boron content is $5.0 \mathrm{wt}$ \% , carbon content is $3.0 \mathrm{wt}$. \% and the temperature is $1515 \mathrm{~K}$. The free energy of the Fe-B-C melt is calculated for the first time by the quasi-chemical method and the surface of thermodynamic stability of the Fe-B-C melt is plotted, depending on temperature and boron and carbon content in the alloy. The results obtained in the paper show that in order to obtain a homogeneous Fe-B-C melt, which does not contain any microheterogeneous structure in the form of short-order microregions, it is necessary to perform the overheating more than to $180 \mathrm{~K}$ for the region where the primary phase is iron, and no less than to $200 \mathrm{~K}$ for the regions with boron cementite and boride.

KEY WORDS: $\mathrm{Fe}-\mathrm{B}-\mathrm{C}$ system alloys, $\mathrm{Fe}_{2} \mathrm{~B}$ boride, $\mathrm{Fe}_{3}(\mathrm{CB})$ boron cementite, eutectics, thermodynamic stability of a melt.

The Fe-B-C system alloys have good physical properties, such as hardness and wear resistance, corrosion resistance $[1-4]$.

The processes occurring in the melts of alloys are known to affect the phase composition of the alloys after crystallization. To predict these processes, the thermodynamic stability of the melt should be determined.

The study of the phase composition of Fe-B-C alloys is paid much attention [4-8]. Investigation of $\mathrm{Fe}_{0.68} \mathrm{~B}_{0.16} \mathrm{C}_{0.6}$ (at. \%) and $\mathrm{Fe}_{0.76} \mathrm{~B}_{0.06} \mathrm{C}_{0.18}$ (at. \%) alloys shows that formation of cubic boron carbide $\mathrm{Fe}_{23}(\mathrm{BC})_{6}$ occurs after annealing at $1073 \mathrm{~K}$. After annealing of these specimens at $1273 \mathrm{~K}$, the formation of $\mathrm{Fe}_{3}(\mathrm{BC})$ boron cementite is observed, and by means of DTA (differential thermal analysis) it is determined that the solid state is formed at $1400 \mathrm{~K}$ [5, 9].

The authors of [4] note that when boron content is 1.0-3.0 wt. \% in the Fe-B-C alloy after crystallization the formation of $\gamma$-iron primary phase occurs at the temperature of $1422 \mathrm{~K}$. This is in agreement with the results of the authors [6]. With increase in boron content in the alloy up to $3.8 \mathrm{wt}$. \%, the primary phase after crystallization is $\mathrm{Fe}_{2} \mathrm{~B}$ boride.

The liquidus surface of the Fe-B-C alloys was first obtained by G. Tammann, the ternary eutectic point is represented at this surface at boron content of $2.9 \mathrm{wt} . \%$ and carbon content of $1.5 \mathrm{wt} . \%$, and at the temperature of $1383 \mathrm{~K}$. The authors of [8] points out that the eutectic point occurs at boron content of $2.6 \mathrm{wt} . \%$ and carbon content of 1.5 wt. \%, at the temperature of $1339 \mathrm{~K}$, and in Ref. [10] it is stated that there is a minimum of boron and carbon content and the temperature at $1.5 \mathrm{wt}$ \% boron and $2.5 \mathrm{wt}$. \% carbon at $1402 \mathrm{~K}$ on the liquidus surface.

Thus, currently the temperature of liquidus surface as a function of boron and carbon content for the $\mathrm{Fe}-\mathrm{Fe}_{2} \mathrm{~B}-$ $\mathrm{Fe}_{3}(\mathrm{CB})$ alloys is not unanimous. For the moment there are no data available on the homogeneity and thermodynamic stability of Fe-B-C melts.

The purpose of this study is to derive of the liquidus temperature dependence on boron and carbon content in the alloy and to determine the homogeneity limit of the $\mathrm{Fe}_{-}-\mathrm{Fe}_{2} \mathrm{~B}-\mathrm{Fe}_{3}(\mathrm{CB})$ melt.

\section{MATERIALS AND METHODS}

The investigation was carried out for the specimens with boron content of $0.005-7.0 \mathrm{wt} . \%$ and carbon content of 0.4-6.67 wt. \%, the rest was iron. To obtain the Fe-B-C alloys, we used such constituents: carbonyl iron (with iron content of $99.95 \mathrm{wt}$ \%), amorphous boron (with boron content of $97.5 \mathrm{wt} \%$ ), graphite (with carbon content of 99.96 wt. \%). The smelting of specimens was performed in a Tammann furnace in the alundum crucibles in argon 
atmosphere. The cooling rate of the alloys was $20 \mathrm{~K} / \mathrm{min}$. To determine the chemical composition of alloys, chemical and spectral analyses were used [11]. To reveal the peculiarities of phase transformations in the Fe-B-C system alloys, differential thermal analysis (DTA) of 72 specimens was performed by means of derivatograph.

The phase composition of alloys was studied by method of X-ray microanalysis by means of JSM-6490 microscope with ASID-4D scanning head and "Link Systems 860" software energy-dispersive X-ray microanalyser, and by means of optical microscope "Neophot-21". The X-ray electron probe analysis was carried out using internal standards. The X-ray and X-ray diffraction analyses were performed with DRON-3 diffractometer in monochromated $\mathrm{Fe}-\mathrm{K}_{\alpha}$ radiation.

\section{RESULTS AND DISCUSSION}

Study of the liquidus temperature in the Fe-B-C system alloys and the primary phases in relation to boron and carbon content, shows that at $3.0 \mathrm{wt}$. \% boron and $0.65 \mathrm{wt}$. \% carbon the formation of $\gamma$-Fe primary crystals occurs while crystallization in the temperature range of $1417-1420 \mathrm{~K}$. In the temperature range of $1397-1403 \mathrm{~K}$ the $\gamma-\mathrm{Fe}+\mathrm{Fe}_{2} \mathrm{~B}$ eutectics formation occurs, and at $1393-1396 \mathrm{~K}$ the $\gamma$-Fe+Fe $3(\mathrm{CB})$ eutectics appears. The $\gamma-\mathrm{Fe} \leftrightarrow \alpha$-Fe transformation takes place at the temperature of $996 \mathrm{~K}$ (Fig. 1).
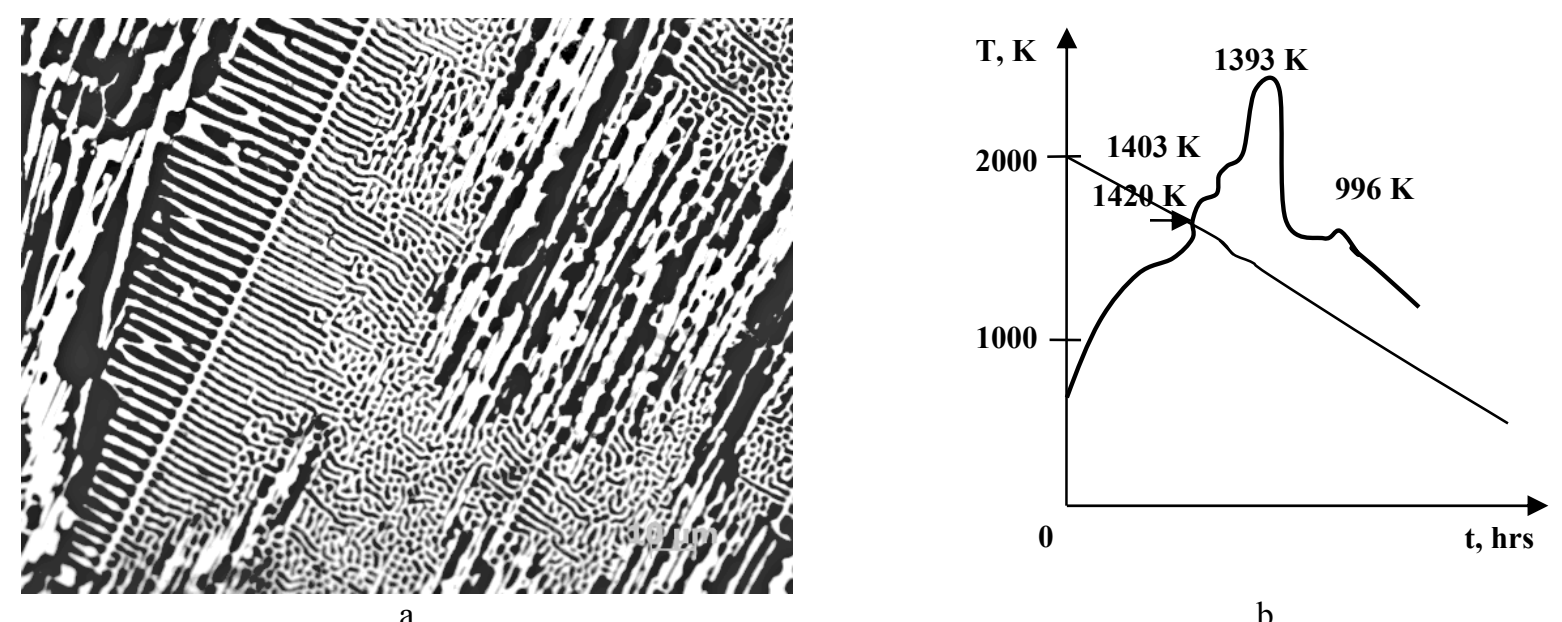

Fig. 1. The microstructure, $\times 800$ (a), DTA curve (b) of the alloy with boron content of 3.0 wt. $\%$ and carbon content of 0.65 wt. $\%$

The microhardness for iron is $389.5 \mathrm{GPa}$, for the $\gamma-\mathrm{Fe}+\mathrm{Fe}_{2} \mathrm{~B}$ eutectics $-897.2 \mathrm{GPa}$, and for the $\gamma-\mathrm{Fe}+\mathrm{Fe}_{3}(\mathrm{CB})$ eutectics - 755.4 GPa.

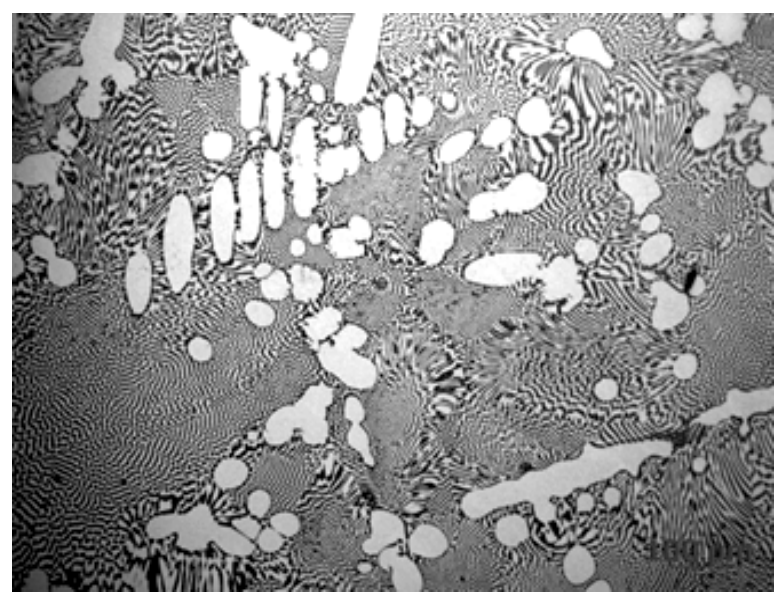

$\mathrm{a}$

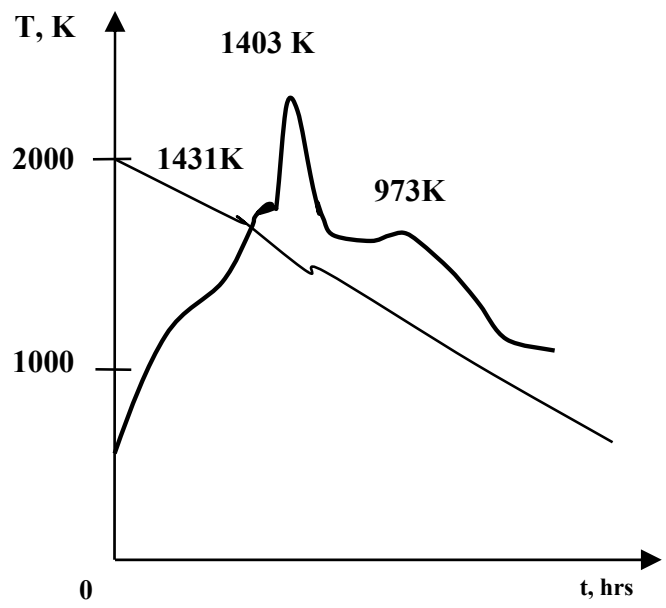

b

Fig. 2. The microstructure, $\times 500$ (a), DTA curve (b) of the alloy with boron content of 3.43 wt. $\%$ and carbon content of 2.25 wt. $\%$

Investigation of the alloys with $0.3-5.5 \mathrm{wt}$. \% boron and $2.1-6.6 \mathrm{wt}$. \% carbon shows that the primary crystals in the process of crystallization are $\mathrm{Fe}_{3}(\mathrm{CB})$ boron cementite formed within the temperature range of $1427-1431 \mathrm{~K}$. At further cooling the formation of the $\gamma-\mathrm{Fe}+\mathrm{Fe}_{3}(\mathrm{CB})$ eutectics with lamellar morphology is observes in the temperature range of 1387-1403 K (Fig. 2). The $\gamma$-Fe↔ $\leftrightarrow$-Fe transformation is detected at the temperature of $973 \mathrm{~K}$.

The results of durometric analysis reveals that the microhardness of boron cementite is $723.1 \mathrm{GPa}$, and that for the $\gamma-\mathrm{Fe}+\mathrm{Fe}_{3}(\mathrm{CB})$ eutectics is $675.8 \mathrm{GPa}$. 
For the alloys with $2.2-8.8 \mathrm{wt}$ \% boron and $0.5-2.1 \mathrm{wt}$ \% carbon during the crystallization the formation of primary crystals of $\mathrm{Fe}_{2} \mathrm{~B}$ iron boride occurs. In certain parts of the structure the primary borides are observed surrounded with the shell consisting of $\mathrm{Fe}_{3}(\mathrm{BC})$ boron cementite and the $\alpha-\mathrm{Fe}+\mathrm{Fe}_{3}(\mathrm{BC})$ eutectics with morphology similar to that of the boride eutectics $\left(\alpha-\mathrm{Fe}+\mathrm{Fe}_{2} \mathrm{~B}\right)$ (Fig. 3a).

The results of differential thermal analysis indicates that the primary crystals of boride are formed from the melt in the temperature range of $1498-1533 \mathrm{~K}$ and surrounded with boron cementite shell appeared during the peritectic transformation $\mathrm{L}+\mathrm{Fe}_{2} \mathrm{~B} \rightarrow \mathrm{Fe}_{3}(\mathrm{CB})$ at $1388-1433 \mathrm{~K}$; the $\gamma-\mathrm{Fe}+\mathrm{Fe}_{3}(\mathrm{CB})$ eutectics is formed at the constant temperature of $1399 \mathrm{~K}$, which implies the possibility of the four-phase transformation $\mathrm{L}+\mathrm{Fe}_{2} \mathrm{~B} \rightarrow \gamma-\mathrm{Fe}+\mathrm{Fe}_{3}(\mathrm{CB})$ and the transformation $\gamma$-Fe↔ $\alpha$-Fe at $925 \mathrm{~K}$ (Fig. 3c). The microhardness for iron boride is $1123.6 \mathrm{GPa}$, for boron cementite - 789.1 GPa, and for eutectics - 863.2 GPa.

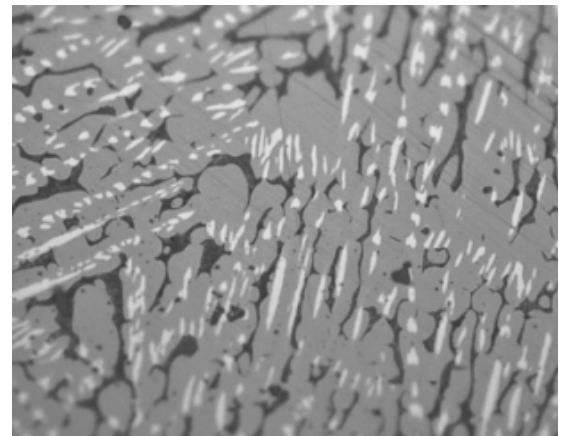

a

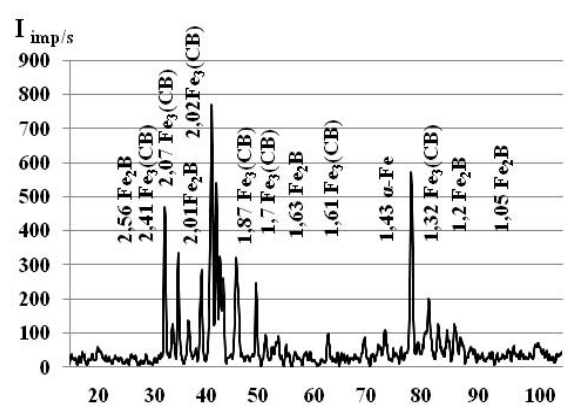

$\mathrm{b}$

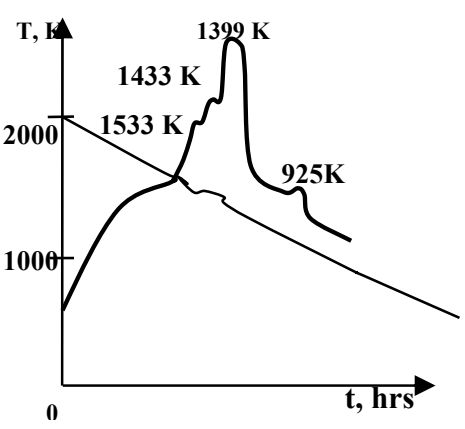

$\mathrm{c}$

Fig. 3. The microstructure (a), diffractogram (b), DTA curve (c) of the alloy with $2.5 \mathrm{wt}$ \% boron and 4.0 wt. $\%$ carbon

The findings show that the liquidus temperature for Fe-B-C system alloys is low compared to binary Fe-B and Fe$\mathrm{C}$ alloys. This is in agreement with the results of other authors [12].

The study of microstructure, XRD and DTA for 72 specimens allows us to construct the liquidus surface for the alloys of Fe-B-C system (Fig. 4).

One of the important factors affecting the formation of the alloys structure under cooling is determination of the liquid stability, i.e. the temperature when the homogeneity of the liquid is observed and there are no any microcrystalline formations.

The Helmholtz free energy is known to be a function of independent variables $F=F\left(V, T, x_{\mathrm{i}}\right)$, where $V$ is a volume, $T$ is a temperature, $x_{i}$ is a weight content of elements, $i=1,2,3,4\left(x_{1}=x_{\mathrm{Fe}}, x_{2}=x_{\mathrm{B}}, x_{3}=x_{\mathrm{C}}, x_{4}=x_{\mathrm{V}}\right.$ (vacancy)). Provided that there are no any external force and change in volume ( $V=$ const, $p=$ const) the total differential of Helmholtz free energy is written in a form

$$
d F=d U-d(T S)+d(p V)=-S d T+\sum_{i=1}^{4} \mu_{i} d x_{i},
$$

where $U$ is the internal energy. Correspondingly, the thermodynamic forces are the entropy $S=-\left(\frac{\partial F}{\partial T}\right)_{x_{i}}$, and the chemical potential of the constituent in compound $\mu_{i}=\left(\frac{\partial F}{\partial x_{i}}\right)_{T}$.

To determine the phase stability, let us find the variation of Helmholtz free energy:

$$
\delta F=\sum_{n=1}^{\infty} \frac{1}{n !}\left[\delta T \frac{\partial}{\partial T}+\delta x_{1} \frac{\partial}{\partial x_{1}}+\delta x_{2} \frac{\partial}{\partial x_{2}}+\delta x_{3} \frac{\partial}{\partial x_{3}}+\delta x_{4} \frac{\partial}{\partial x_{4}}\right]^{n} F .
$$

The general condition of the phase stability by Gibbs is that arbitrary variations of the internal energy and external parameters of the system should not cause both reversible and irreversible processes in the system (to keep the system in equilibrium), so they must be such that [13]:

$$
\delta U-T \delta S+p \delta V-\mu_{1} \delta x_{1}-\mu_{2} \delta x_{2}-\mu_{3} \delta x_{3}-\mu_{4} \delta x_{4}>0 .
$$

So, to determine the thermodynamic stability of the Fe-B-C system melt, we use the approach proposed by the author of [14].

The determinant of stability for the melt is: 


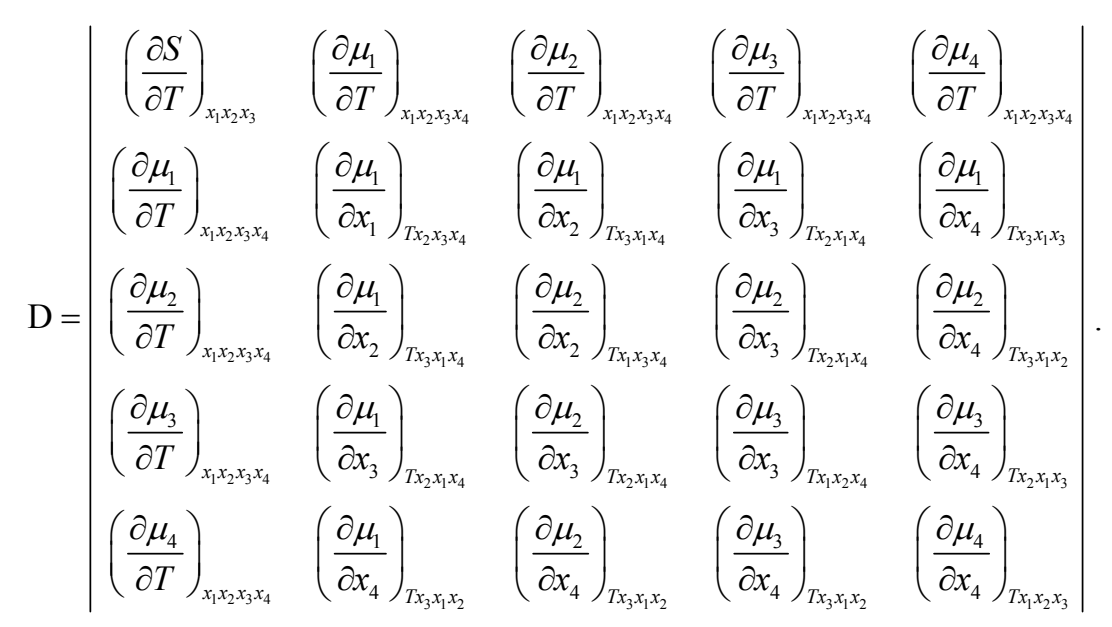

The case of $D=0$ was first defined by J. W. Gibbs as a critical state of matter [15]. During the supercritical transitions the determinant and coefficients of stability pass through finite minima that correspond to the growth of fluctuations. The locus of these minima is a low-stability curve. It should be noted that for different coefficients of stability, the curves of lowered stability may not be coinciding. For these reasons the curve of lowered stability for $D$, which includes all equilibrium characteristics of the system and therefore best describes its stability, is used as a basis. The threshold case of supercritical transitions when fluctuations in the system reach the maximum level, the determinant and coefficients of stability pass zero minima, is the critical state. So, let us find when $d D=0$.

The Helmholtz free energy we find by the quasi-chemical method as:

$$
\begin{aligned}
F & =11\left(N_{1} N_{1} v_{11}+N_{1} N_{2} v_{12}+N_{1} N_{3} v_{13}+N_{2} N_{2} v_{22}+N_{3} N_{3} v_{33}+N_{3} N_{4} v_{34}+\right. \\
& \left.+N_{2} N_{4} v_{24}+N_{1} N_{4} v_{14}\right)+11 k T\left(\left(N_{1}+N_{2}+N_{3}+N_{4}\right) \ln \left(N_{1}+N_{2}+N_{3}+N_{4}\right)-,\right. \\
& \left.-N_{1} \ln N_{1}-N_{2} \ln N_{2}-N_{3} \ln N_{3}-N_{4} \ln N_{4}\right)
\end{aligned}
$$

where $T$ is the temperature $(\mathrm{K}), v_{i j}$ is the interaction energy of components $(\mathrm{J} / \mathrm{mol})$.

To calculate the free energy of the melt, we used the values of energies of interactions between the components from the works [15-20]. The sum is taken over all $i$ and $j$ provided $i \neq j$.

From Eq. (4) we obtain the thermodynamic functions of the melt:

$$
\begin{aligned}
& S=-\left(\frac{\partial F}{\partial T}\right)_{x_{i}}=-k\left(\left(x_{1}+x_{2}+x_{3}+x_{4}\right) \ln \left(x_{1}+x_{2}+x_{3}+x_{4}\right)-x_{1} \ln \left(x_{1}\right)-x_{2} \ln \left(x_{2}\right)-x_{3} \ln \left(x_{3}\right)-x_{4} \ln \left(x_{4}\right)\right) \\
& \mu_{1}=\left(\frac{\partial F}{\partial x_{1}}\right)_{T x_{2} x_{3} x_{4}}=22 x_{1} v_{11}+11 x_{2} v_{12}+11 x_{3} v_{13}+11 x_{4} v_{14}+k T\left(\ln \left(x_{1}+x_{2}+x_{3}+x_{4}\right)-\ln \left(x_{1}\right)\right) \\
& \mu_{2}=\left(\frac{\partial F}{\partial x_{2}}\right)_{T x_{1} x_{3} x_{4}}=11 x_{1} v_{12}+22 x_{2} v_{22}+11 x_{4} v_{24}+k T\left(\ln \left(x_{1}+x_{2}+x_{3}+x_{4}\right)-\ln \left(x_{2}\right)\right) \\
& \mu_{3}=\left(\frac{\partial F}{\partial x_{3}}\right)_{T x_{1} x_{2} x_{4}}=11 x_{1} v_{13}+22 x_{3} v_{33}+11 x_{4} v_{34}+k T\left(\ln \left(x_{1}+x_{2}+x_{3}+x_{4}\right)-\ln \left(x_{3}\right)\right) \\
& \mu_{4}=\left(\frac{\partial F}{\partial x_{4}}\right)_{T x_{1} x_{2} x_{3}}=11 x_{1} v_{14}+11 x_{2} v_{24}+11 x_{3} v_{34}+k T\left(\ln \left(x_{1}+x_{2}+x_{3}+x_{4}\right)-\ln \left(x_{4}\right)\right) \\
& \left(\frac{\partial \mu_{1}}{\partial x_{1}}\right)_{T x_{1} x_{2} x_{3}}=22 v_{11}+k T\left(1 /\left(x_{1}+x_{2}+x_{3}+x_{4}\right)-1 / x_{1}\right),\left(\frac{\partial \mu_{1}}{\partial T}\right)_{x_{1} x_{2} x_{3} x_{4}}=k\left(\ln \left(x_{1}+x_{2}+x_{3}+x_{4}\right)-\ln \left(x_{1}\right)\right) \\
& \left(\frac{\partial \mu_{1}}{\partial x_{2}}\right)_{T x_{1} x_{3} x_{4}}=11 v_{12}+k T /\left(x_{1}+x_{2}+x_{3}+x_{4}\right), \\
& \left(\frac{\partial \mu_{1}}{\partial x_{3}}\right)_{T x_{1} x_{2} x_{4}}=11 v_{13}+k T /\left(x_{1}+x_{2}+x_{3}+x_{4}\right),\left(\frac{\partial \mu_{1}}{\partial x_{4}}\right)_{T x_{1} x_{2} x_{3}}=11 v_{14}+k T /\left(x_{1}+x_{2}+x_{3}+x_{4}\right)
\end{aligned}
$$




$$
\begin{aligned}
& \left(\frac{\partial \mu_{2}}{\partial x_{2}}\right)_{T x_{1} x_{3} x_{4}}=22 v_{22}+k T\left(1 /\left(x_{1}+x_{2}+x_{3}+x_{4}\right)-1 / x_{2}\right),\left(\frac{\partial \mu_{2}}{\partial T}\right)_{x_{1} x_{2} x_{3} x_{4}}=k\left(\ln \left(x_{1}+x_{2}+x_{3}+x_{4}\right)-\ln \left(x_{2}\right)\right), \\
& \left(\frac{\partial \mu_{2}}{\partial x_{1}}\right)_{T x_{2} x_{3} x_{4}}=11 v_{12}+k T /\left(x_{1}+x_{2}+x_{3}+x_{4}\right) \\
& \left(\frac{\partial \mu_{2}}{\partial x_{3}}\right)_{T x_{1} x_{2} x_{4}}=k T /\left(x_{1}+x_{2}+x_{3}+x_{4}\right),\left(\frac{\partial \mu_{2}}{\partial x_{4}}\right)_{T x_{1} x_{2} x_{3}}=11 v_{24}+k T /\left(x_{1}+x_{2}+x_{3}+x_{4}\right) \\
& \left(\frac{\partial \mu_{3}}{\partial x_{3}}\right)_{T x_{1} x_{2} x_{4}}=22 v_{33}+k T\left(1 /\left(x_{1}+x_{2}+x_{3}+x_{4}\right)-1 / x_{3}\right) \text {, } \\
& \left(\frac{\partial \mu_{3}}{\partial T}\right)_{x_{1} x_{2} x_{3} x_{4}}=k\left(\ln \left(x_{1}+x_{2}+x_{3}+x_{4}\right)-\ln \left(x_{3}\right)\right),\left(\frac{\partial \mu_{4}}{\partial x_{4}}\right)_{T x_{1} x_{2} x_{3}}=k T\left(1 /\left(x_{1}+x_{2}+x_{3}+x_{4}\right)-1 / x_{4}\right) \\
& \left(\frac{\partial \mu_{4}}{\partial T}\right)_{x_{1} x_{2} x_{3} x_{4}}=k\left(\ln \left(x_{1}+x_{2}+x_{3}+x_{4}\right)-\ln \left(x_{4}\right)\right),\left(\frac{\partial \mu_{3}}{\partial x_{1}}\right)_{T x_{2} x_{3} x_{4}}=11 v_{13}+k T /\left(x_{1}+x_{2}+x_{3}+x_{4}\right), \\
& \left(\frac{\partial \mu_{3}}{\partial x_{2}}\right)_{T x_{1} x_{3} x_{4}}=k T /\left(x_{1}+x_{2}+x_{3}+x_{4}\right),\left(\frac{\partial \mu_{3}}{\partial x_{4}}\right)_{T x_{1} x_{2} x_{3}}=11 v_{34}+k T /\left(x_{1}+x_{2}+x_{3}+x_{4}\right), \\
& \left(\frac{\partial \mu_{4}}{\partial x_{1}}\right)_{T x_{2} x_{3} x_{4}}=11 v_{14}+k T /\left(x_{1}+x_{2}+x_{3}+x_{4}\right),\left(\frac{\partial \mu_{4}}{\partial x_{2}}\right)_{T x_{1} x_{3} x_{4}}=11 v_{24}+k T /\left(x_{1}+x_{2}+x_{3}+x_{4}\right) \text {, } \\
& \left(\frac{\partial \mu_{4}}{\partial x_{3}}\right)_{T x_{1} x_{2} x_{4}}=11 v_{34}+k T /\left(x_{1}+x_{2}+x_{3}+x_{4}\right)
\end{aligned}
$$

To determine the stability of the melt, the condition $d D=0$ should be fulfilled:

$$
d D=\left(\frac{\partial D}{\partial T}\right)_{x_{1} x_{2} x_{3} x_{4}} d T+\left(\frac{\partial D}{\partial x_{1}}\right)_{T x_{2} x_{3} x_{4}} d x_{1}+\left(\frac{\partial D}{\partial x_{2}}\right)_{T x_{1} x_{3} x_{4}} d x_{2}+\left(\frac{\partial D}{\partial x_{3}}\right)_{T x_{1} x_{2} x_{4}} d x_{3}+\left(\frac{\partial D}{\partial x_{4}}\right)_{T x_{1} x_{2} x_{3}} d x_{4}=0 .
$$

The condition (5) holds when

$$
\left(\frac{\partial D}{\partial T}\right)_{x_{1} x_{2} x_{3} x_{4}}=0, \quad\left(\frac{\partial D}{\partial x_{1}}\right)_{T x_{2} x_{3} x_{4}}=0,\left(\frac{\partial D}{\partial x_{2}}\right)_{T x_{1} x_{3} x_{4}}=0,\left(\frac{\partial D}{\partial x_{3}}\right)_{T x_{1} x_{2} x_{4}}=0,\left(\frac{\partial D}{\partial x_{4}}\right)_{T x_{1} x_{2} x_{3}}=0 .
$$

The resulting system of equations (6) is solved numerically using the mathematical package Maple. The solution of system of equations (6) is shown in Fig. 4.

The experimental results obtained in this study enable to construct the liquidus surface, and calculated data allow plotting the surface of thermodynamic stability of the melt (Fig. 4). The liquidus surface of the Fe-B-C alloys was first obtained by G. Tammann; the ternary eutectic point with 2.9 wt. \% boron and $1.5 \mathrm{wt}$ \% carbon at $1383 \mathrm{~K}$ was mapped on this surface. The ternary eutectic point is the intersection of the curves of monovariant binary eutectics.

The liquidus surface study presented in [10] indicates that the ternary eutectic point occurs at boron content of 1.5 wt. $\%$ and carbon content of 2.5 wt. $\%$ and at the temperature of $1402 \mathrm{~K}$.

The results obtained in this work reveal that at the liquidus surface in Fe-B-C alloys there is a minimum at boron content of 2.9 wt. $\%$ and carbon content of $1.3 \mathrm{wt} . \%$ at $1375 \mathrm{~K}$. The findings are in good agreement with data given in [5], where it is pointed out that the solidus temperature is $1400 \mathrm{~K}$. In this paper it is shown experimentally the existence of a quasi-binary section and the coordinates of the peritectic point are fixed: the boron content is $5.0 \mathrm{wt}$ \%, carbon content is $3.0 \mathrm{wt} . \%$ and the temperature is $1515 \mathrm{~K}$.

The process of the formation of the primary phases has a great effect on the structural state and phase transformations in the alloy. At the moment there are lack of data on determining and investigating the homogeneity of the melt of Fe-B-C alloys without any microcomplexes. According to the outcomes, to obtain the homogeneous Fe-B-C melt (without any microheterogeneous structure in the form of short-range microregions) where the primary crystals are $\gamma$-Fe phase, it is necessary to perform the overheating more than to $180-200 \mathrm{~K}$. For the alloys with boron and carbon content close to the quasi-binary cross-section, to obtain the homogeneous melt it is necessary to perform the overheating of alloy more than to $220-250 \mathrm{~K}$. 


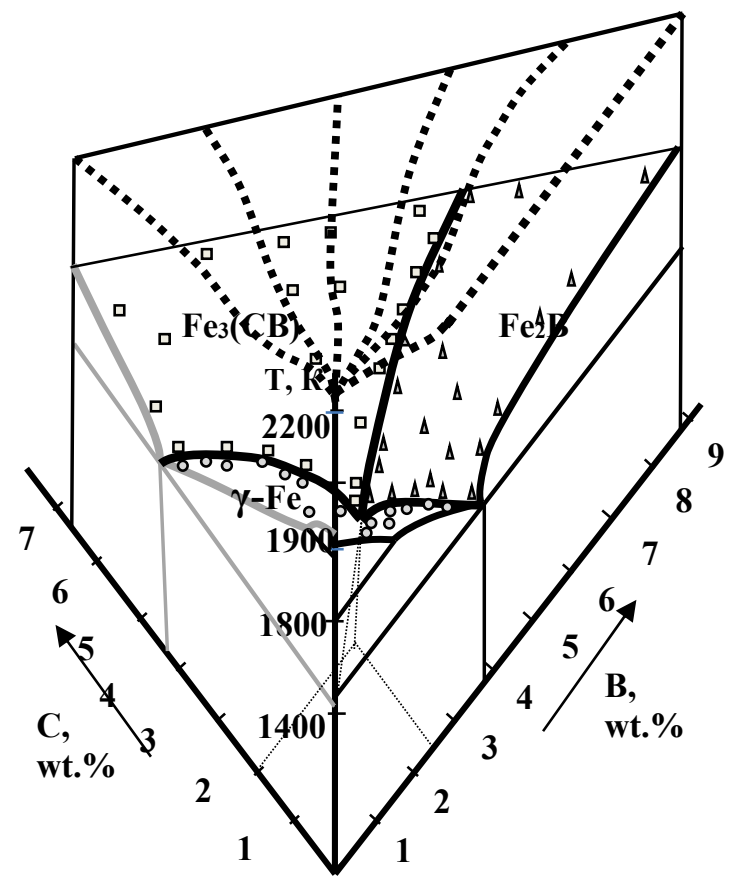

Fe

Fig. 4. The state diagram of the Fe-B-C system $\left(\square-\mathrm{Fe}_{3}(\mathrm{CB}), \Delta-\mathrm{Fe}_{2} \mathrm{~B}, \mathrm{O}-\gamma-\mathrm{Fe}\right)$ and the surface of thermodynamic stability of the melt ( - - the Fe-B diagram, _ - the Fe-C diagram, - - the eutectics curves, ..... - the surface of thermodynamic stability of the Fe-B-C melt)

\section{CONCLUSION}

In the paper the phase composition and phase transformation occurring in the alloys with boron content of $0.005-7.0 \mathrm{wt}$. \% and carbon content of 0.4-6.67 wt. \% (the rest is iron) is studied. It is shown that formation of the primary phases $\gamma$ - $\mathrm{Fe}, \mathrm{Fe}_{2} \mathrm{~B}$ and $\mathrm{Fe}_{3}(\mathrm{CB})$ takes place depending on boron and carbon content in the alloys.

The liquidus surface is plotted experimentally for the Fe-B-C system alloys in the concentrarion range of $0-8.85$ wt. \% boron and $0-6.65 \mathrm{wt} . \%$ carbon and it is shown that the ternary eutectic point occurs at the liquidus surface in the alloys of Fe-B-C systems with boron content of $2.9 \mathrm{wt} . \%$ and carbon content of $1.3 \mathrm{wt} . \%$ at the temperature of $1375 \mathrm{~K}$.

In this paper, using the quasi-chemical methos, we obtain for the first time the temperature dependence of the Helmholtz free energy of the Fe-B-C melt. We obtain the dependences of the temperature of thermodynamic stability of the melt on boron and carbon content in the alloy and plot the surface of concentration anomaly without any microcomplexes in the melt. According to the outcomes, it is necessary to perform the overheating more than to $180 \mathrm{~K}$ to obtain the homogeneous Fe-B-C melt, which does not contain the microheterogeneous structure in the form of shortorder microregions.

The work was performed within the specific project "Resurs" KC063.18 "Development of chemical composition and technological decisions for the manufacture of railway wheels for different application and their maintainability" of the NAS of Ukraine.

\section{ORCID IDs}

다atalia Yu. Filonenko https://orcid.org/0000-0003-1219-348X, (1)Alexandra N. Galdina https://orcid.org/0000-0003-2311-8506

\section{REFERENCES}

[1] Fu Han-guang, Nonferrous Metals. 9, 113 (2005), http://en.cnki.com.cn/Article en/CJFDTotal-ZZZZ200509006.htm.

[2] Zhao Guorong, Li Zhenhua, Liu Meihong, He Zhengyuan, Hot Working Technology. 15, 113 (2011), http://en.cnki.com.cn/Article en/CJFDTotal-SJGY201115001.htm.

[3] Song $\mathrm{Xu}, \mathrm{Fu}$ Han, Yang Jun, Transactions of Materials and Heat Treatment. 10, 164 (2008), http://en.cnki.com.cn/Article en/CJFDTOTAL-JSCL200801010.htm.

[4] P. Sang, H. Fu, Y. Qu, C. Wang and Y. Lei, Materials Science \& Engineering Technology. 46(9), 962 (2015), https://doi.org/10.1002/mawe.201500397.

[5] Ayako Sudo, Tsuyoshi Nishi, Noriko Shirasu, Masahide Takano and Masaki Kurata, Journal of Nuclear Science and Technology. 52(10), 1308 (2015), https://doi.org/10.1080/00223131.2015.1016465. 
[6] Xiangyi Ren, Hanguang Fu, Jiandong Xing, Yongwei Yang and Shuli Tang, Journal of Materials Research. 32(16), 3078 (2017), https://doi.org/10.1557/jmr.2017.304.

[7] Zhi Fu Huang, Jian Dong Xing, Sheng Qiang Ma, Yi Min Gao, Ming Zheng and Li Qiu Sun, Key Engineering Materials. 732, 59 (2017), https://doi.org/10.4028/www.scientific.net/KEM.732.59.

[8] I.M. Spiridonova, S.B. Pilyaeva, E.B. Syxovaya, E.B. Zinkovskiy, Visnyk Dnipropetrovskogo nacionalnogo universytetu. Serija Fizyka. Radioelektronika, 8, 32-44 (2002). (in Ukrainian)

[9] N.Yu. Filonenko, S.B. Pilyaeva, Journal of V.N. Karazin Kharkiv National University, series "Physics", 21(1135), 49-51 (2014), https://periodicals.karazin.ua/physics/article/view/7817/7290. (in Ukrainian)

[10] Eberhard Schürmann, Clausthal, Shao-Xiong Li, Jilin Bor 37. Jahrgang,121-129 (1985).

[11] S.V. Tverdokhlebova, Visnyk Dnipropetrovskogo nacionalnogo universytetu. Serija Fizyka. Radioelektronika, 14(12/1), 100-104 (2007), http://www.vdnu.narod.ru/v14/pdf/s26_14.pdf. (in Ukrainian)

[12] Takafumi Hibino, Teruo Bitoh, Journal of Alloys and Compounds. 707(15), 82 (2017), https://doi.org/10.1016/j.jallcom.2016.12.060.

[13] E.D. Soldatova, Journal of Molecular Liquids. 127(1-3), 99 (2006), https://doi.org/10.1016/j.molliq.2006.03.027.

[14] N.Yu. Filonenko, East. Eur. J. Phys. 5(1), 55-60 (2018), https://doi.org/10.26565/2312-4334-2018-1-06.

[15] J.W. Gibbs, Термодинамика. Статистическая механика [Thermodynamic. Statistical Mechanics], (Moscow, Nauka, 1982), pp. 584. (in Russian)

[16] Tian Wei He, Ye Hua Jiang, Rong Zhou, Jing Feng, RSC Advances. 51, 45250 (2016), https://doi.org/10.1039/C6RA05969D.

[17] D. Terentyev, K. Heinola, A. Bakaev and E. E. Zhurkin, Scripta Materialia. 86, 9 (2014), https://doi.org/10.1016/j.scriptamat.2014.04.003.

[18] T. Ohnuma, N. Soneda and M. Iwasawa, Acta Materialia. 57, 5947 (2009), https://doi.org/10.1016/j.actamat.2009.08.020.

[19] N.Yu. Filonenko, O.S. Baskevych and V.V. Soboliev, Journal Scientific Bulletin of National Mining University. 4, 74 (2012), http://nv.nmu.org.ua/index.php/en/component/jdownloads/finish/34-04/528-2012-4-filonenko/0.

[20] O.Yu. Bereza, N.Yu. Filonenko, O.S. Baskevich, Physics and Chemistry of Solid State, 13(3), 968-973 (2012), http://page.if.ua/uploads/pcss/vol13/1304-21.pdf. (in Ukrainian)

\section{ПОВЕРХНЯ ЛІКВІДУСУ ТА СПІНОДАЛЬ СПЛАВІВ СИСТЕМИ Ғе-В-С Н.Ю. Філоненко ${ }^{\mathrm{a}, \mathrm{b}}$, О.М. Галдіна ${ }^{\mathrm{c}}$ \\ аД3 «Дніпропетровська державна медична академія МОЗ Украӥни» 49044, Украӥна, м. Дніпро, вул. Володимира Вернадського, 9

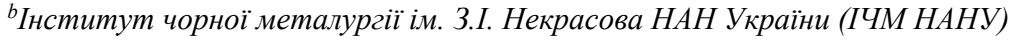 49107, Україна, м. Дніпро, пл. Ак. Стародубова К.Ф., 1 \\ сДніпровський начіональний університет імені Олеся Гончара 49010, Україна, м. Дніпро, просп. Гагаріна, 72}

В даній роботі дослідження здійснювали на зразках сплавів системи Fe-B-C з вмістом бору 0,005-7,0\% (мас.) та карбону 0,4-6,67\% (мас.), інше - залізо. За результатами мікроструктурного, рентгеноструктурного та диференційного термічного аналізів визначені первинні фази та температури їх утворення. В залежності від вмісту бору (в інтервалі 1,5-8,80\% (мас.)) та карбону (0,5-6,67\% (мас.)) в сплавах системи Fe-B-C первинними фазами при кристалізації $\epsilon$-Fe, бороцементит Fез(CB) та борид $\mathrm{Fe}_{2} \mathrm{~B}$. За результатами експерименту, проведеного в даній роботі, досліджено фазовий склад та фазові перетворення, що відбуваються в сплавах, та побудована поверхня ліквідусу. Дослідження, проведені в даній роботі, показали, що сплави системи Fe-B-C мають низьку температуру ліквідусу у порівнянні з бінарними сплавами Fe-B та Fe-C. На поверхні ліквідусу сплавів системи Fe-B-C існує точка при вмісті бору 2,9\% (мас.) та карбону 1,3\% (мас.), яка має найменшу температуру 1375 К та є точкою перетину моноваріантних евтектик, що корелює з результатами інших авторів. Мікроструктура сплавів, розташованих на лініях моноваріантних евтектик, представлена: евтектиками $\gamma-\mathrm{Fe}+\mathrm{Fe}_{2} \mathrm{~B}, \gamma-\mathrm{Fe}+\mathrm{Fe}_{3}(\mathrm{CB})$ та первинними кристалами бориду заліза $\mathrm{Fe}_{2} \mathrm{~B}$ в оболонці з бороцементиту $\mathrm{Fe}_{3}(\mathrm{BC})$. Експериментально в даній роботі показано існування квазібінарного перерізу та визначені координати точки перитектики: при вмісті бору 5,0 \% (мас.) та карбону 3,0 \% (мас.) та температурі 1515 К. Вперше квазіхімічними методом отримано вільну енергію та побудовано поверхню термодинамічної стійкості розплаву $\mathrm{Fe}-\mathrm{B}-\mathrm{C}$ в залежності від температури та вмісту бору й карбону в сплаві. Отримані в роботі результати показали, що для досягнення однорідного розплаву Fe-B-C, що не містить мікронеоднородної структури у вигляді мікроділянок з ближнім порядком, необхідно виконати перегрів: для ділянки, де первинною фазою є залізо, більш ніж на 180 К, а для ділянок, що містять бороцементит та борид, - не менш ніж на $200 \mathrm{~K}$.

КЛЮЧОВІ СЛОВА: сплави системи $\mathrm{Fe}-\mathrm{B}-\mathrm{C}$, борид $\mathrm{Fe}_{2} \mathrm{~B}$, бороцементит $\mathrm{Fe}_{3}(\mathrm{CB})$, евтектика, термодинамічна стійкість розплаву.

\section{ПОВЕРХНОСТЬ ЛИКВИДУСА И СПИНОДАЛЬ СПЛАВОВ СИСТЕМЫ Fе-В-С} Н.Ю. Филоненко ${ }^{\mathrm{a}, \mathrm{b}}$, А.Н. Галдина ${ }^{\mathrm{c}}$

${ }^{a} Г У$ «Днепропетровская государственная медииинская академия МОЗ Украины» 49044, Украина, г. Днепр, ул. Владимира Вернадского, 9

${ }^{b}$ Институт черной металлургии им. З.И. Некрасова НАН Украины (ИЧМ НАНУ) 49107, Украина, г. Днепр, ул. Ак. Стародубова К.Ф., 1

сДнепровский национальный университет имени Олеся Гончара 49010, Украина, г. Днепр, просп. Гагарина, 72

В данной работе исследования осуществляли на образцах сплавов системы $\mathrm{Fe}-\mathrm{B}-\mathrm{C}$ с содержанием бора 0,005-7,0\% (мас.) и углерода $0,4-6.67 \%$ (мас.), остальное - железо. По результатам микроструктурного, рентгеноструктурного и дифференциального термического анализов определены первичные фазы и температуры их образования. В зависимости от содержания бора и углерода (бора в интервале $1,5-8,80 \%$ (мас.) и углерода 0,5-6,67\% (мас.)) в сплавах системы Fe-B-C при кристаллизации первичными фазами являются: $\gamma$ - $\mathrm{Fe}$, бороцементит $\mathrm{Fe}_{3}(\mathrm{CB})$ и борид $\mathrm{Fe} 2 \mathrm{~B}$. По результатам эксперимента, 
проведенного в данной работе, исследованы фазовый состав и фазовые превращения, которые происходят в сплавах, и построена поверхность ликвидуса. Исследования, проведенные в данной работе, показали, что сплавы системы Fе-B-C имеют более низкую температуру ликвидуса по сравнению с бинарными сплавами Fe-B и Fe-C. На поверхности ликвидуса сплавов системы Fe-B-C существует точка с содержанием бора 2,9\% (мас.) и углерода 1,3\% (мас.), которая имеет наименьшую температуру 1375 К и является точкой пересечения моновариантных эвтектик, что коррелирует с результатами других авторов. Микроструктура сплавов, расположенных на линиях моновариантних эвтектик, представлена: эвтектиками $\gamma-\mathrm{Fe}_{2}+\mathrm{Fe}_{2} \mathrm{~B}, \gamma-\mathrm{Fe}+\mathrm{Fe}_{3}(\mathrm{CB})$ и первичными кристаллами боридов железа $\mathrm{Fe}_{2} \mathrm{~B}$ в оболочке из бороцементита $\mathrm{Fe}_{3}(\mathrm{BC})$. Экспериментально в данной работе показано существование квазибинарного сечения и определены координаты точки перитектики: при содержании бора 5,0\% (мас.) и углерода 3,0\% (мас.) и температуре 1515 К. Впервые с использованием квазихимического метода получена свободная энергия и построена поверхность термодинамической устойчивости расплава $\mathrm{Fe}-\mathrm{B}-\mathrm{C}$ в зависимости от температуры и содержания бора и углерода в сплаве. Полученные в работе результаты показали, что для достижения однородного расплава Fe-B-C, который не содержит микронеоднородной структуры в виде микроучастков с ближним порядком, необходимо выполнить перегрев: для участка, где первичной фазой является железо, более чем на $180 \mathrm{~K}$, а где первичными фазами являются бороцементит и борид - не менее чем на $200 \mathrm{~K}$.

КЛЮЧЕВЫЕ СЛОВА: сплавы системы $\mathrm{Fe}-\mathrm{B}-\mathrm{C}$, борид $\mathrm{Fe}_{2} \mathrm{~B}$, бороцементит $\mathrm{Fe}_{3}(\mathrm{CB})$, эвтектика, термодинамическая устойчивость расплава. 